\title{
金沢方式による聴覚障害児の長期読書力経過
}

新家 惠子・能登谷晶子・鈴木 重忠

室野亜希子・古川 仍

\section{Long-Term Progress in the Reading Abilities of Hearing-Impaired Children Trained by the Kanazawa Method}

\author{
Keiko Araie, Masako Notoya, Shigetada Suzuki \\ Akiko Murono and Mitsuru Furukawa \\ (School of Medicine, Kanazawa University)
}

\begin{abstract}
Speech and language training for hearing-impaired children at our clinic is done by the Kanazawa Method which consists of reception and expression training in sign language as well as auditory/oral language and written language training. The present investigation was undertaken to explore long-term progress in reading abilities in 14 hearing-impaired children who had participated in the Kanazawa Method before entering elementary schools. Progress in reading ability was evaluated using the New Diagnostic Reading Ability Test of the Kyoken Method.

The results obtained were as follows:

1) The average score in reading ability just before entering elementary schools reached the second grade.

2) Ten children (71.4\%) maintained a high score longitudinally.

3) There was a significant correlation between reading achievement level at 6 years of age and the later level $\left(r_{s}=0.62\right)$.

4) The reading achievement level of our children was higher than that of those trained by the conventional method.

These results suggest that early instruction in written language is effective in the acquisition of reading ability which is especially difficult for the hearing-impaired.
\end{abstract}

Key words : hearing-impaired children, early instruction in written language, reading ability, long-term progress

はじめに

聴覚障害児の言語力は, 音声言語のみならず文字言語 においても著しい遅れが認められ，我国では「9歳の壁」 を超えることは困難である1)と言われている.

そこで, 我々は約 20 年前より, 聴能と読話による言語 訓練のみでは, 聴覚障害児の言語発達遅滞の解決に限界 があるといら観点から, 乳幼児期から聴覚読話法と併用 して文字言語や手指法を導入している(金沢方式, 文字
・音声法)、この金沢方式による言語訓練の結果, 聴覚 障害児にとって, 文字言語は以下の利点を持つことが, すでに報告されている2) 7). (1) 1 歳前後より理解可能で ある. (2)音声言語が未発達でも習得が可能である. (3)音 声言語より習得が容易である. (4)聴覚・読話を経由して, 音声言語に移行する. (5)語や文構造を把握しやすい. (6) 音声言語の発達技よび読話の学習を促進する.

本研究では，金沢方式で訓練した聴覚障害児の読書力 
について，長期経過を分析した．それをもとに乳幼児期 から文字言語を導入することが，「9歳の壁」を超える ために有用であるか否かについて検討をしたので報告す る.

\section{対象と方法}

(1) 対 象

対象は，当科で乳幼児期から金沢方式によって言語訓 練を受けた先天性聴覚障害児で, 生活年齢が 9 歳以上に 達した14例である. 学年別内訳は, 小学 5 年生は 6 名で, そのうち女子が 3 名で，男子が 3 名である． 6 年生は 6 名で, そのうち女子が 4 名で, 男子が 2 名である. 中学 1 年生は女子 1 名, 2 年生は女子 1 名で, 全員普通学校 に在学している(表 1).

初診時年齢は, 0 歳代 1 名, 1 歳代 7 名, 2 歳代 5 名, 4 歳代 1 名で, ほとんどの例で 1 歳または 2 歳から当科 で言語訓練を始めている(図 1 ).

平均聴力レベルは $90 \mathrm{~dB}$ 未満が 5 名, $90 \mathrm{~dB}$ 以上が 9 名で，そのうち 7 名は $100 \mathrm{~dB}$ 以上であった(図 2 ).

聴覚障害の病因については，ほとんどが不明であった。

表 1 対象児の内訳(1994年現在)

\begin{tabular}{cccc}
\hline \hline 学 年 & $\begin{array}{c}\text { 女子 } \\
(\text { 人) }\end{array}$ & $\begin{array}{c}\text { 男 } \\
(\text { 人) }\end{array}$ & $\begin{array}{c}\text { 合 } \\
(\text { 人) }\end{array}$ \\
\hline 小学校 5 年 & 3 & 3 & 6 \\
小学校 6 年 & 4 & 2 & 6 \\
中学校 1 年 & 1 & 0 & 1 \\
中学校 2 年 & 1 & 0 & 1
\end{tabular}

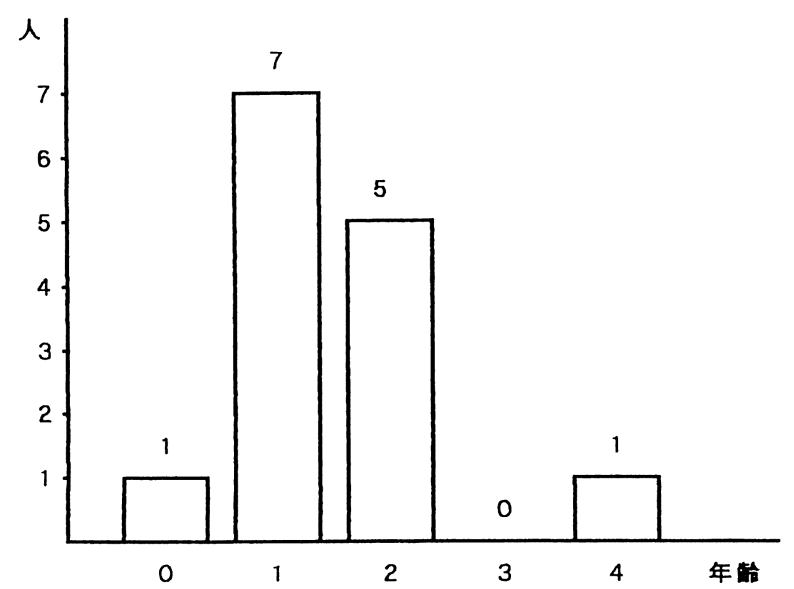

図 1 対象览の初診時年齢分布

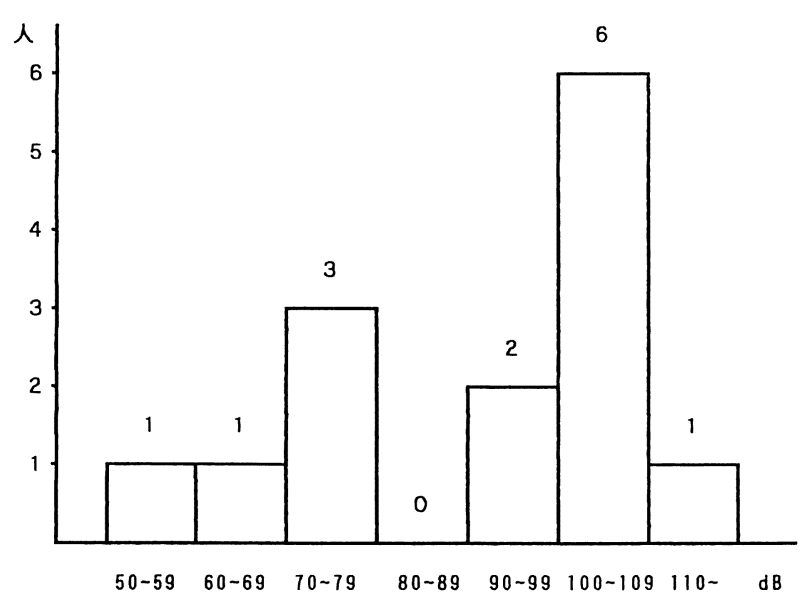

図 2 対象児の平均聴力レベル分布

なお，経過観察中に聴力が著しく悪化した症例はなかっ た。

（2）訓練方法

当科の言語訓練8199) はホームワーク方式である. 2 週 間に 1 回の個別指導では, 毎日の家庭での課題を, 各自 の言語発達レベルと興味に合わせて決定し，母親に指導 している.

子供については聴力検査と言語発達の経過を各種の検 查で評価している。また，週に 1 回の集団訓練を聴能， 読話訓練执よびホームワークの内容を確認する目的で行 っている.さらに，就学前の 1 年間は構音訓練の個別指 導も行っている. 就学後は学期休みの来科時に聴力検査, 構音, 言語力の評価や指導などを行っている.

母親には, 聴覚障害児に対して, 音声刺激と同時に文 字や手話による刺激を，毎日の生活の中で与えるよらに 指導している，手話は単語だけではなく多文節文でも使 用し，文では日本語の語順に合わせて手話を用い，助詞 の部分は指文字を使用している.

文字指導は 1 歳前後より開始しているが，音声刺激も 同時に行っている. 文字は，初期より意味のある単語を 最小単位としている点が，他の文字指導と異なるところ である，具体的には，文字単語カードを家の中の物に貼 付したり，絵カードやジェスチャーとのマッチングを促 すことから始める．その後，1 文節文执よび多文節文の 受信 (読解) と, 文字カードの選択による発信操作を主体 に行っている。 
（3）評価方法

対象児に改訂版教研式全国新読書力診断検査 ${ }^{10)}$ を用 いて, 初回は小学校就学直前 6 歳代に, 就学後は外来来 科時に年 $1 〜 2$ 回施行した.

本検査は小学校低学年 $(1 \sim 3$ 年) 用々高学年 $(4 \sim 6$ 年) 用があり, 下位項目は読速度, 読字力, 読解力, 語 彙力の 4 部から構成されている. 読書力の評価は, 総点 から読書学年および読書力偏差值と読書力評価段階 ( 5 段階評価)で表示される. 今回は, 就学直前の読書力評 価段階が 3 以上(偏差值45以上)の対象児を良好群に， 2 以下 (偏差値45未満)を不良群に分けて，長期経過を比較 検討した。

\section{結 果}

(1) 就学直前の読書力

対象児の小学校就学直前 6 歳代の読書力は， 5 段階評 価では平均3.43段階で, 読書学年は平均 2 年 1 学期レベ ルであった。

評価段階が 3 以上の良好群は 12 名 $(85.7 \%)$ で，平均 3.67 段階であった。評価段階が 2 以下の不良群は 2 名 $(14.3 \%)$ で，平均2.00段階であった。

良好群 12 名の平均聴力レベルは, $90 \mathrm{~dB}$ 以上が 8 名, $90 \mathrm{~dB}$ 未満が 4 名であった．不良群 2 名の平均聴力レべ ルは, $90 \mathrm{~dB}$ 以上が 1 名, $90 \mathrm{~dB}$ 末満が 1 名であった(表
2 ).

（2）読書力の長期経過

生活年齢が 10 歳以上に達した対象児全体の読書力は, 5 段階評価では平均 3.21 段階であった。良好群は 10 名 (71.4\%)で平均3.80段階であった。，不良群は 4 名(28.6 \%)で, 平均 1.75 段階であった.

良好群 10 名の平均聴力レベルは, $90 \mathrm{~dB}$ 以上が 6 名, $90 \mathrm{~dB}$ 未満が 4 名であった。 不良群 4 名の平均聴力レベ ルは, $90 \mathrm{~dB}$ 以上が 3 名, $90 \mathrm{~dB}$ 末満が 1 名であった(表 3 ).

就学直前の読書力と高学年になった時の読書力の相関 を検討した。 その結果，両者には有意に高い相関 $\left(\mathrm{r}_{\mathrm{s}}=\right.$ $0.62, \mathrm{P}<0.05$ ) が認められた（図 3 ). な抏，対象児のほ とんどが, 1 ～歳から言語訓練を開始して拈り, 就学 直前の読書力と対象児の訓練開始時の年齢との関連性を 明らかにすることは困難であった。

（3）他の言語訓練法との比較

広田ら ${ }^{11)}$ は幼児期に聴覚・ロ話法による言語訓練を 受けた聴覚障害児の読書力を検討しているので，本研究 の対象児の読書力と比較した. 5 段階評価の段階 3 以上 を良好群，それ以下を不良群に分けた。広田らの入学当 初の読書学年は平均 1 年 3 学期レベルであったといら. また，入学当初の良好群は $49.1 \%$ あったのに比し，高 学年時は36.8\%に低下していた(図 4).

表 2 対象児の平均聴力レベルと読書力(就学直前)

\begin{tabular}{|c|c|c|c|c|c|c|}
\hline $\begin{array}{c}\text { ( } 5 \text { 読軞 } \\
\end{array}$ & F価） & $\begin{array}{c}90 \mathrm{~dB} \text { 末満 } \\
(\text { 人) }\end{array}$ & $\begin{array}{c}90 \mathrm{~dB} \text { 以上 } \\
\text { (人) }\end{array}$ & 計 & \multicolumn{2}{|c|}{ 平均読書力 } \\
\hline \multirow{2}{*}{ 不良群 } & 1 & 0 & 0 & 0 & \multirow{2}{*}{2.00} & \multirow{5}{*}{3.43} \\
\hline & 2 & 1 & 1 & 2 & & \\
\hline \multirow{3}{*}{ 良好群 } & 3 & 2 & 3 & 5 & \multirow{3}{*}{3.67} & \\
\hline & 4 & 1 & 5 & 6 & & \\
\hline & 5 & 1 & 0 & 1 & & \\
\hline
\end{tabular}

表 3 対象児の平均聴力レベルと読書力(10歳以上)

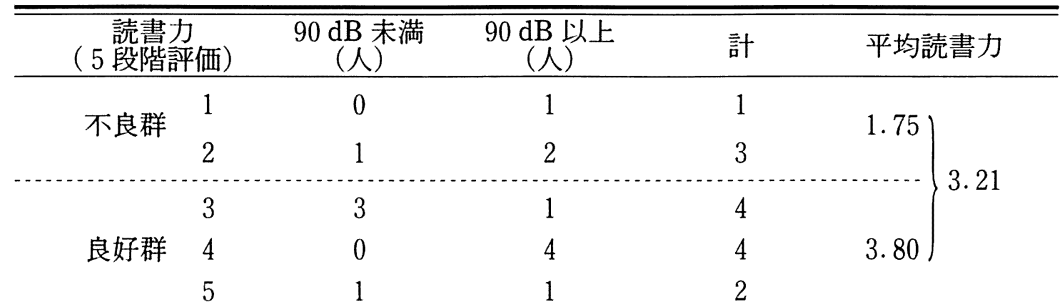




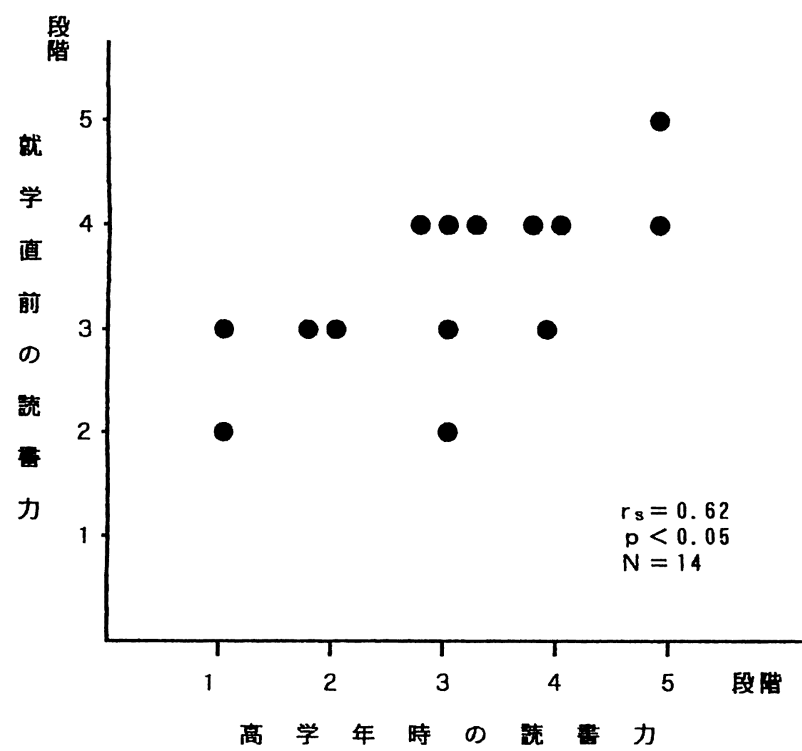

図 3 就学直前と高学年時の読書力の相関

\section{金沢方式の訓練による読書力（14例）}

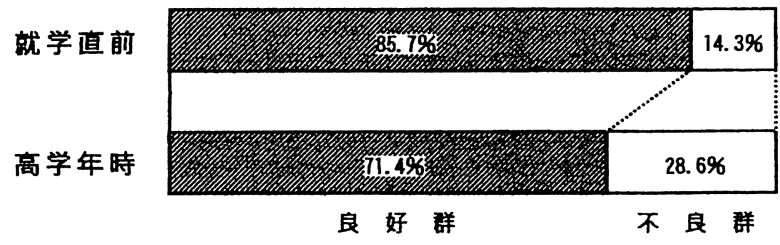

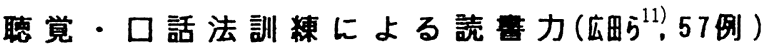

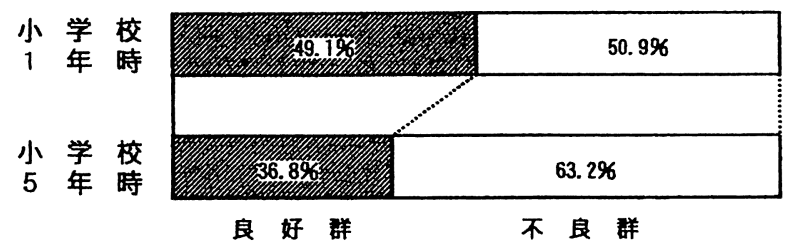

図 4 訓練法の違いによる読書力の比較

\section{考察}

本研究では，乳幼児期から金沢方式で言語訓練を受け た聴覚障害児14名の読書力について検討した. その結果， 小学校就学前に行った読書力検査で, 平均小学校 2 年 1 学期のレベルに達していた． 5 段階評価では， 3 以上の 良好群に属していたものが，対象児の $85.7 \%$ にんだ.
すなわち, 就学前に $80 \%$ 以上の聴覚障害児が，文レベル の読字理解が可能になっていると言える。しかも，音声 受信が不利な $90 \mathrm{~dB}$ 以上の重度聴覚障害児も 9 名中 8 名が良好群に属していたことにより，聴力レベルに左右 されることなく高い読書力が獲得されたことになる.

この高い読書力は対象児が10歳以上になった時点でも， $70 \%$ 以上のもので維持されていた．したがって，就学前 に獲得された高い読書力は，その後も著しい成績の低下 を示さなかったわけである。しかし，わずかであるが 2 名は不良群に移行した.しかも，この 2 名はいずれも 90 $\mathrm{dB}$ 以上の症例であったことから，聴覚障害が重篤例で はとくに就学後も読書力の低下の有無についての注意が 必要であると言える。

一方， $90 \mathrm{~dB}$ 以下の聴カレベルであっても就学前に不 良群に属していた 1 例は，生活年齢が10歳以上に達した 時点でも良好群への移行はなかった. 逆に, $90 \mathrm{~dB}$ 以下 の聴力レベルで就学前に良好群に属していた 4 例は，そ の後の検査でる良好群に入って括り，不良群へ移行する ことはなかった。したがって，90 dB 以下の聴カレベル であっても就学時の読書力がその後の読書力レベルをほ ぼ予想しているとも言える.

以上より聴力の程度にかかわらず高い読書力を獲得し, それを維持するためには，就学時までの読書力の獲得程 度いかんに依ると言える。

聴覚・口話法は, 健聴児の言語獲得過程と同様の順序, すなわち音声言語の土台の上に文字言語を学習する方法 である，一方，我々の金沢方式は，音声言語と文字言語 をほぼ同時期から訓練する方法である点で，聴覚・口話 法と異なっている。

聴覚・ロ話法によって訓練された聴覚障害児の読書力 を報告している広田ら ${ }^{11)}$ の結果では，就学時点で平均 1 年 3 学期レベルであったという． 5 段階評価では 49.1 \%のものが段階 3 以上の良好群に属していたと述べてい る. 金沢方式による本研究の結果では, 前述の上うに平 均 2 年 1 学期レベルで， $85.7 \%$ ものが良好群であった ことより, 就学時点では金沢方式による方が読書力は高 いと言える。

次に, 対象児が 10 歳以上の高学年に達した時点で比較 したが，段階 3 以上の良好群に属していたものが，広田 らの報告では $36.8 \%$ であったのに比し，本研究の対象児 は71.4\%であった．したがって，広田らの報告の対象児 は，就学時点で良好群に属したものが49.1\%であったの 
に比し，10歳以上では $36.8 \%$ にすて低下していたことに なる.一方, 本研究の対象児は, 就学時点の $85.7 \%$ から 10 歳以上で $71.4 \%$ に低下したに過ぎず，広田らの報告で成 績の低下が著しい傾向にあったことになる。

本研究と広田らの報告は, 対象児の聴力レベルや訓練 期間について統一された比較ではないので断言はできな いが，金沢方式で訓練を受けた聴覚障害児の方が高い読 書力を獲得することができ，しかも長期にわたりそれが 維持される傾向があることが示唆された. したがって, 文字言語を乳幼時期の早期より導入することは，「9歳 の壁」を超えるために有用な手段であると言える.

幼览期は軽度であっても難聴による言語発達の影響が 大きいとする報告も散見される12)。一般に, 中等度, 高 度と聴覚障害の程度が厳しくなるほど音声受信が困難と なることが予想される，遅れがちとなる聴覚障害児の語 彙や文の理解・表出を補らものは, 聴覚障害児にとって 文字言語であるとすると, 健聴児に匹敵する言語力を獲 得するためには, 文字言語の早期導入が不可欠であると 考える。

$$
\text { まとめ }
$$

金沢方式で訓練された聴覚障害児の読書力の長期経過 について報告した. 就学直前の読書力は, 平均 2 年 1 学 期レベルであった. 対象児の $71.4 \%$ は, 高学年時になっ ても該当学年以上の読書力を有し，「9歳の壁」を超え ていた. 就学直前の読書力と高学年時の読書力には有意 な相関が認められた. 聴覚・口話法で訓練された聴覚障 害児より，金沢方式で訓練された聴覚障害児の方が，高 い読書力を獲得できることが示唆された。

\section{参考文献}

1 ) 田中美郷：普通学校に括ける難聴児の取扱. 聴覚障害(後 藤修二編)．509頁，医歯薬出版，東京， 1984 .

2 ）鈴木重忠, 金作美矢子: 早期文字指導を行った重度聴覚障 害児の言語発達. 聴覚言語障害 $6: 127 \sim 135,1977$.

3 ) 能登谷晶子, 鈴木重忠, 中島美喜子: 晹幼児 2 例の音声拉 よび文字言語記号の習得過程. 音声言語医学 $20: 69 \sim 76$, 1979.

4 ) 鈴木重忠, 能登谷晶子：1 重度聴覚障害幼児の言語記号学 習過程. 日耳鼻 $82: 263 \sim 270,1979$.

5 ）鈴木重忠, 能登谷晶子：重度聴覚障害幼児の 1 歳代におけ る音声および文字言語の習得成績. 音声言語医学 $21: 240$ 〜247, 1980.

6 ）鈴木重忠, 能登谷晶子, 杉盛 恵: 重度聴覚障害幼児の 2 歳代に扣ける音声扣よび文字言語の習得成績. 音声言語医 学 $22: 271 \sim 275,1981$.

7 ）能登谷晶子, 鈴木重忠 : 難聴幼児の言語発達と文字言語の 役割. 音声言語医学 $25: 140 \sim 146,1984$.

8 ) 能登谷晶子：文字・音声法 (金沢方式) とは. 聴覚障害乳幼 児の新しい言語療法(鈴木重忠, 相野田紀子, 能登谷晶子). $1 \sim 2$ 頁, 石川県言語障害児を持つ親の会, 金沢, 1992 .

9 ) 能登谷晶子 : 文字. 手指指導の実際. 聴覚障害乳幼児の新 しい言語療法(鈴木重忠, 相野田紀子, 能登谷晶子). 16 53 頁, 石川県言語障害児を持つ親の会, 金沢, 1992.

10）阪本一郎, 村石昭三, 佐藤泰正 : 教研式新読書力診断検査. 日本図書文化協会, 東京, 1985 .

11）広田栄子, 工藤多賀, 前田知佳子, 他 : 普通学級に在籍す る感音難聴児の言語能力に関する経過観察. 音声言語医学 $35: 124 \sim 125,1994$.

12）鈴木重忠, 能登谷晶子, 手取屋浩美, 他 : 言語障害幼児に 扣ける軽度難聴. 日耳鼻 $96: 946 \sim 951,1993$.

$$
\left(\begin{array}{l}
\text { 別刷請求先 : 新家惠子 } \\
\text { 干 } 920 \text { 金沢市宝町 } 13-1 \\
\text { 金沢大学医学部耳鼻咽喉科学教室 }
\end{array}\right)
$$

